\title{
The Contribution of Different Patterns of Teachers' Interactions to Young Children's Experiences of Democratic Values During Play
}

\author{
Berit Zachrisen ${ }^{1}$
}

Published online: 8 June 2016

(C) The Author(s) 2016. This article is published with open access at Springerlink.com

\begin{abstract}
Developing a sense of belonging and experiences about the value of community are important democratic values that children may learn during play in preschool. Through the different ways that teachers' interact with children during play, children can learn about democratic values. This study is part of a Nordic project on values education in early childhood education and care settings and data from this project are used in the analyses. The data consisted of video observations from informal play situations in seven Norwegian preschools, with children aged from 18 to 36 months. The nature of practitioners' interactions with the children was explored in the analyses. There were different ways that practitioners interacted during dyadic and group interactions, and they communicated different values about belonging and community. The findings showed that group interactions can safeguard children's opportunities to experience democratic practices in a more comprehensive manner than are available to children in dyadic interactions. It is important that practitioners are aware how different ways of interacting with children in play situations, either in dyadic interactions or group interactions, may result in different values being conveyed to children about democracy.
\end{abstract}

Keywords Children's rights · Child participation - Teacher-child interactions · Preschool $\cdot$ Democratic values · Play

Résumé Lorsqu'ils jouent, les enfants du préscolaire peuvent développer un sentiment d'appartenance et faire l'expérience de la valeur de la communauté, apprenant ainsi d'importantes valeurs démocratiques. Les différentes façons dont les éducateurs interagissent avec les enfants durant le jeu permettent à ces derniers de faire l'apprentissage de valeurs démocratiques. Cette étude fait partie d'un projet

Berit Zachrisen

berit.zachrisen@uis.no

1 Department of Early Childhood Education, University of Stavanger, 4036 Stavanger, Norway 
des pays nordiques sur l'éducation aux valeurs dans les services d'éducation et de garde des jeunes enfants, et des données de ce projet ont été utilisées dans les analyses. Les données consistent en des observations vidéo de situations de jeu informelles dans sept centres préscolaires norvégiens, avec des enfants âgés de 18 à 36 mois. Les analyses ont examiné la nature des interactions des éducateurs avec les enfants. Les éducateurs interagissent de différentes manières dans les interactions dyadiques ou de groupe. Ils transmettent aussi des valeurs différentes sur l'appartenance et la communauté. Les résultats révèlent que les interactions en groupe peuvent assurer aux enfants des occasions de vivre des expériences démocratiques et ce, de façon plus complète que lors d'interactions dyadiques. Il est important que les éducateurs comprennent comment les différents modes d'interactions avec les enfants dans des situations de jeu, en interaction dyadique ou en groupe, peuvent avoir pour résultat de transmettre aux enfants des valeurs différentes sur la démocratie

Resumen Desarrollar un sentido de la pertenencia y experiencias sobre el valor de la comunidad son valores democráticos importantes que los menores pueden aprender durante la etapa preescolar. A través de las distintas formas en las que los profesores actúan con los niños durante el juego, estos pueden aprender valores democráticos. Este estudio es parte de un proyecto nórdico sobre la educación en valores, en el marco de la atención y educación de la primera infancia (AEPI), y los datos de este proyecto se usan en los análisis. Los datos están compuestos por observaciones mediante videos de situaciones de juego en siete centros preescolares de Noruega con niños de entre 18 y 36 meses. En los análisis se estudió la naturaleza de las interacciones de los profesores con los menores. Hubo distintas formas en las que los profesores interactuaron durante las actividades didácticas y en grupo, y comunicaron distintos valores sobre la pertenencia y la comunidad. Los hallazgos mostraron que las interacciones en grupo pueden garantizar a los niños la oportunidad de experimentar prácticas democráticas de una manera más completa que las que ofrecen a los menores las interacciones didácticas. Es importante que los profesores sean conscientes de cómo las distintas interacciones con los niños en situaciones de juego, ya sean actividades didácticas o en grupo, pueden dar lugar a una transmisión de valores sobre la democracia distintos a los menores

\section{Introduction}

In an increasingly globalized world, there has been growing interest in questions relating to democratic citizenship and education, especially in Western countries, but also worldwide (Biesta 2011; Osler and Starkey 2005). According to Osler and Starkey (2005), education for democratic citizenship is based on the idea that everyone can contribute to shape society. Democratic values are expressed in the daily encounters between children and between practitioners and children in preschool (Biesta 2011; Quennerstedt 2011). The study is part of a Nordic project on values education in ECEC settings and presents some results based on the 
Norwegian research material. The aim of this study is to investigate the interaction between children and practitioners in relation to democratic practices in preschool.

The data consist of video observations of interactions between children and practitioners in play situations. In Nordic preschools, play has a central position, and it is emphasized in all Nordic curricula as an important arena for children's learning and interaction with other children (Einarsdttir et al. 2015). Through play, children establish contacts, gain important developmental experiences and enact their lives. The article describes the challenge in finding a balance between the individual and the collective as a key task of pedagogical work with democratic values in a preschool.

\section{Theoretical Background}

This study has taken inspiration from Dewey (2008/1916) and Biesta (2011), who have a special interest in education for democracy and the learning of democratic values in educational institutions. These researchers emphasize participation in noncoerced, reflective communication as a way to learn about democracy.

Dewey (1988/1939) maintained that democracy can be described as a frame of reference that surrounds educational institutions. A frame of references can better be understood as an idea and an ideal rather than as a clearly designed social model. Democracy is first and foremost a way of life and a way of being together with other people. Good situations for learning democratic attitudes are encounters characterized by reciprocal and free dialogue rather than by power dynamics and competition. Children should experience a peaceful and mutually respectful social environment (Dewey 1988/1939).

Biesta (2011) is critical of a one-sided understanding of education for democracy as merely a transfer of certain skills. In such a perspective, educational institutions emerge as instruments with the aim to produce good citizens. The mistake of such an understanding is the excessive focus on learning about democratic citizenship rather than how democratic citizenship is enacted in daily experiences. The former interpretation can also be criticized because citizenship emerges as a result of the educational process (Biesta 2011). This may give the impression that children are not yet fully grown citizens but are in a transitional phase, and they will become mature citizens at a later stage. Such views lead to a risk of neglecting or underestimating the importance of the situations children live and participate in every day for their education for democracy. A shift from teaching about citizenship to learning through democratic participation in daily situations will also involve a shift from focusing on children as isolated individuals to seeing them as persons who are related to each other (Biesta 2011). One of the issues stressed as important in education for democracy is rich, diverse experiences. Such experiences can help individuals develop different views of what constitutes a good life, which values are important, and what gives meaning to one's life (Biesta 2011).

Based on Dewey's (2008/1916) and Biesta's (2011) connections of democracy, this study focuses on daily encounters with other children and practitioners in preschool as essential to children's understanding of democratic values. Accordingly, dialogue and interactions are considered to be key factors in the learning 
process. This conception of democracy requires viewing children and adults as equal partners; however, the distribution of power and responsibilities is not equal. According to Bae (2009b), there is a risk of overestimating children as autonomous, competent and rational actors, and correspondingly, underestimating their dependency and vulnerability. This can cause an overly narrow view of children as social actors in preschool. This study takes a balanced view of children as both autonomous and competent and dependent and vulnerable. The children are seen as active participants in all interactions in which they take part. However, the practitioners have a specific responsibility as key actors and mediators of values in preschool.

\section{Previous Research}

This section will discuss previous research regarding the communication of democratic values in the interaction between children and practitioners in preschool. Much of the research in this field consists of Nordic studies (Emilson and Johansson 2016; Quennerstedt 2011). Nordic studies will have a primary focus in the following section.

The interaction between children and practitioners is a key element in the creation of democratic practices in preschool (Quennerstedt 2011; Thomas and Percy-Smith 2010). Some studies highlight how different forms of communication between children and practitioners can influence children's opportunities to participate in and influence this interaction (Bae 2009a; Palludan 2005). Palludan (2005) singles out two modes of practitioners' communication with children: teaching and exchange. The teaching mode constructs the child as an object for the practitioners' teaching. The emphasis is on introducing, explaining and instructing. The child's role is to listen and to answer the practitioner's questions or follow his/ her guidelines. The exchange mode constructs the child as a subject and an equal interaction partner. The child/children and the practitioner exchange experiences, interpretations and knowledge, taking turns asking and answering questions. Closely related to the exchange mode are Bae's (2009a) spacious interactional patterns. Such patterns open up opportunities for children's initiatives and creativity and also for equal interactions between children and practitioners. Narrow patterns, involving extensive control on the part of the practitioner in the form of closed questions, corrections or pointing out rules, seem to limit children's opportunities to have their world of experiences confirmed. According to Bae (2009a), a genuine understanding of democracy may arise when a child receives respect for his or her expressions and speech and realizes through experience that we all need each other.

Different forms of communication can generate different values. Communicative actions are highlighted by Emilson and Johansson (2009) as a key in the communication of democratic values in preschools (Habermas 1996). Communicative actions represent intersubjectivity and include playfulness and curiosity. If a practitioner consciously or unconsciously uses strategic actions to communicate democratic values, the form of communication can counteract the values he or she is trying to communicate and change them, for example, into disciplinary values (Emilson and Johansson 2009). 
The most common approach to participation in preschool seems to be individually oriented (Emilson and Johansson 2016). Some researchers recommend a deliberative democracy practice in education, where individuals are seen as vital members of important communities (Biesta 2011; Cockburn 2010). A challenge for such a practice in preschools is to create fair, collective agreements. According to Tholin and Jansen (2011), a polyphonic perspective on democratic processes, where different voices are heard, can be an alternative approach. With such an approach the goal will not necessarily be to achieve a collective agreement but to connect individual voices to a polyphonic choir with a diversity of voices.

The interaction between children and practitioners can be explored from multiple perspectives. The aim of this study is to contribute to the knowledge about the connection between interaction patterns and democratic practices in a preschool context. A search for interaction patterns can shed light upon some common features of the analysed interactions. At the same time, there is a risk of losing sight of important differences inside the dominant patterns. This challenge is met by identifying both main patterns and part patterns. The research question examined in this study is as follows: What connection exists between different interaction patterns and the communication of democratic values in play situations?

\section{Method}

The study can be described as field-based. The research was conducted in the context of Norwegian preschools, where the children spend from 6 to $9 \mathrm{~h}$ each day. The research material consists of video observations with seven preschools. Written informed consent for participation in video observations was obtained from the practitioners and the children's parents. In addition, each observation required sensitivity towards the children's reactions to being filmed. The study met all ethical requirements. Observations were performed in one department in each preschool, both in formal and informal situations. In total, the data included $98 \mathrm{~h}$ of video observations recorded over a period of three semesters.

This analysis was based on 37 video observations from play situations. Play situations are informal situations where the children may choose what they want to engage in. The children were aged from $1 \frac{1}{2}$ to 3 years. The video clips lasted from 4 to $22 \mathrm{~min}$. The end of an interaction was defined either by a marked shift of the activity or by most of the participants leaving the camera focus. The participants in the video observations included (approximately) 21 practitioners and 110 children. Approximately $33 \%$ of the practitioners were preschool teachers, while the others were assistants. The majority of the practitioners were women.

Video has both strengths and weaknesses as a research tool. One strength is that it can reveal many details of daily life (Walsh et al. 2007). The same scene can be replayed repeatedly, and new details that were not noticed in the initial experience can be explored. At the same time, a video clip can be limited. In this case, other researchers had taped the videos. Thus, I did not have direct participation in the situations and missed contextual information, such as what was happening offcamera and around the taped scene in the classroom. A reflexive attitude, which 
involves a self-critique of my own significance to the results, was a critical component in the analysis process. The interpretations and alternative interpretations were tested in relation to one another and to the material as a whole so the parts and the whole would not be in conflict (Erickson 2006). In addition, some of the observations and analyses were discussed with other researchers in the main project, and some of these persons had taped the videos and could thus provide some further information. Discussions with these researchers must be seen as integral to the interpretations and findings.

\section{The Analysis}

The analysis process was inspired by ethnographic analysis (Hammersley and Atkinson 1996). It can be described in three steps, but it should not be understood as a linear process. More correctly, it can be described as a "spiral motion". I have gone back and forth between the steps and developed a deeper understanding of the research material (Creswell 2007). In the first step, I sought to identify communications in play situations, with a certain duration and concentration of interplay between the children and the practitioners.

In the analyses, I focused on both verbal and nonverbal communication, and these aspects are seen as integrated. Nonverbal communication includes glances, facial expressions, verbal sounds, signs of listening, touch, chronemics, physical gestures, postures and movements. The selected video observations were played several times and transcribed. I searched for key aspects of the interactions between children and practitioners. A main feature appeared to be how the practitioners related to the children as separate individuals and/or as valuable members of a collective. A key question in the analysis was: How can the interaction between the practitioners and the children be interpreted in the light of emphasizing the individual and/or the collective?

In most of the interactions, the practitioners seemed to direct their attention towards the children as separate individuals. However, in a few interplays, the practitioners directed their attention more towards the interaction between the children and towards the children as a group. This formed the basis for the construction of two main patterns of interactions: dyadic interactions and group interactions. In a further examination of the observations, important differences within the two main patterns were identified, and six sub-patterns were constructed. Because the number of observations in this study is small, these sub-patterns can be understood more as examples of sub-categories rather than an exhaustive list.

In the second step of the analysis, an exploration was made of the connection between the interaction patterns and children's opportunities to experience different dimensions of central democratic values such as belonging and community. The two values are interrelated and cannot be sharply divided.

Community is seen as a society of people. The value of community is connected with opportunities and conditions to take part in, or choose not to take part in, a group (Johansson et al. 2015). Various qualities of the community include how closed or open it appears and which possibilities exist for developing social bonds and experiencing equal and respectful relationships. For children to experience the 
value of community in the preschool, it is also important to provide space for diverse, individual expressions. An important question in the analysis was: What opportunities are given in the interaction to experience the value of community?

Opportunities to experience the value of community may also provide opportunities to develop a sense of belonging to the group. Belonging, as a democratic value, means to have some bonds to a group based on affection and allegiance. It is not an exact entity, and different degrees of belonging can be explored (Walton et al. 2012). Belongingness is a fundamental emotional need to be an accepted and respected member of a group (Maslow 1981; Walton et al. 2012). This study understands the value of belonging as a sense of relatedness connected to positive, lasting bonds between children or between children and adults. Important factors of developing a sense of belonging to other people are to be treated with respect and recognition and to share experiences. A central question in the analysis was: Which opportunities to develop a sense of belonging with other participants are given in the interaction?

The interaction patterns emphasize how the individual and the collective are given various weights in pedagogical work with democratic values in preschool. In the final step of the analysis, an important question was: How can the orientation be balanced towards the individual and the collective of the youngest children in play situations?

\section{Findings}

This paper presents the two main interaction patterns and six sub-patterns. The two main patterns of interaction are dyadic interaction and group interaction, each with three sub-patterns. Since space is limited, the sub-patterns will not be presented equally thoroughly. However, their different meanings will be described. Different interaction patterns can occur in different parts of the same situation, and sometimes they flow seamlessly into one another. Normally there are transitions between subpatterns within a main pattern. Transitions between main patterns occur less frequently. However, a transition between main patterns could be a communication, which shifts from flowing mainly between one practitioner and each child in a group, to flowing among all the participants. This would be a transition from a dyadic interaction to a group interaction. If the shift is towards a situation where the communication over an extended period, only flow between the practitioner and one of the children, it would have been a transition from one dyadic sub-pattern to another (from dyadic interaction with parallel interaction processes to dyadic interaction in a one-to-one situation). The discussion in relation to these interaction patterns highlights how values of belonging and community are expressed, interact with one another and can sometimes be in conflict.

\section{Dyadic Interaction}

Dyadic interaction is an interaction between a practitioner and one or more children. The lines of communication run mainly between the practitioner and each child. 
There is little interaction between the children, either verbally or nonverbally. The practitioner's focus is primarily on individual children. Similarly, the children's attention is directed towards the practitioner. Metaphorically, the practitioner in a dyadic interaction can be described as a sun with a certain number of planets (children) orbiting around her. Using its gravity (attention), the sun keeps the planets in place.

Three sub-patterns of dyadic interaction were identified. The first is called dyadic interaction in a one-to-one situation. Interactions occur during play periods, often of short duration, where one practitioner interacts with one child over a certain period of time. The practitioner may, for example, convey interest in what a child is dedicated to, play with him or her, or give the child physical or emotional care. Such interactions can emerge either when a child and a practitioner are alone in an area or when they are surrounded by other children and adults. In the following observation, a dyadic interaction in a one-to-one situation emerges when other children surround the couple:

Two children (both two years old) and a practitioner are sitting on the floor. The children are sitting on the practitioner's right side. One of the children has a picture book on his lap while the other one is thumbing through the book. The practitioner is looking towards them, but she does not interfere in the boys' joint activity. Another child of the same age comes from behind and makes physical contact with her. The practitioner grabs the child and lifts him up and puts him on her lap. Then, she begins to rock the child back and forth while she smiles and sings a song. The child smiles back and plays with her. One of the children sitting next to the practitioner looks towards them and then goes away, the other child maintains his interest in the book.

The practitioner emerges as both attentive and responsive to the child who is involved in the playful, dyadic interaction. This child appears to have strong opportunities to experience respect, recognition and shared experiences in the interplay with her. However, one of the other children leaves the group when the practitioner starts to play with the new child. Why he leaves is not clear. One interpretation is that the practitioner's redirecting of her focus of attention towards the new boy triggers the departure. When a practitioner, over an extended period, gives all her attention to one child in a group, the others may feel that they are neglected or excluded from the community. Initially, the practitioner's physical and mental presence may support the interplay between the two boys who are reading a book together. However, after the arrival of the new boy, none of the children receive any support from the practitioner to build relationships with their peers and experience the value of peer community. The opportunities to develop a sense of belonging among the three boys appear to be limited.

Two other dyadic interaction patterns are dyadic interaction with parallel interaction processes and dyadic interaction within a common theme. These two patterns have much in common. In both, one practitioner maintains many conversations on diverse or related topics with different children in parallel. The main lines of the interaction flow between the practitioner and each individual child, and to a lesser extent among the children. In the research material, there are 
examples of practitioners who keep five to six parallel conversations going with different children simultaneously. The following interaction is identified as a dyadic interaction within a common theme:

A girl and a boy, both two years old, are sitting on the floor with a practitioner. Each child has a Barbie doll, and the children are brushing the dolls' long hair with a hairbrush. The children have their faces turned towards the practitioner. The practitioner is responding to each child's verbal utterances, and she looks towards her communication partner. After a while, two new girls (both two years old) join the group and are immediately included in the activity by the practitioner. One of the new girls sits down on the practitioner's lap, and the practitioner accepts this. The other new girl finds a place on the floor. The three children on the floor are now forming a circle with the practitioner. Each child has a doll and some equipment, which they play with. Their utterances are directed towards the practitioner. After a while, the practitioner leaves the group. Two of the children immediately stand up and walk after her.

The main lines of communication are between the practitioner and each child. The children seem aware of each other, and they sometimes look towards the other children when those children are communicating with the practitioner. Particularly, this applies for the girl on the practitioner's lap, who sits with her face turned towards the other children. All the children seem to inspire each other's play and act within a common play idea.

The practitioner is inclusive towards the new children, and she is responsive and present in the interaction. Her communication with the children supports their verbal statements and is important in keeping the group together. When she leaves the group, two of the children follow her.

The practitioners' responsiveness towards each child can to some degree give the children opportunities to experience a sense of belongingness and the value of community with the practitioner. The children sit together in a limited physical space, but they relate to and communicate with each other only to a minor degree. Though they are playing with the same kind of toy, they do not align their actions in common, social play. Thus, the children have restricted opportunities to develop a feeling of shared involvement and to experience the value of "we". A tendency to experience the other children as competitors for the practitioners' attention seems to be more prominent as opposed to experiencing the others as important partners in play.

The practitioner interacts with the children mainly as individuals. She responds to the children's verbal inputs, and to some degree gives room for different expressions. However, the focus on each individual child seems to overshadow her attention on the children as potential playmates for each other. The interaction mainly seems to support the children's sense of belonging and community with the practitioner.

\section{Group Interaction}

While the main lines of communication in a dyadic interaction run between one practitioner and one child, the main lines of communication in a group interaction 
run between the practitioner and the children as important members of a peer group. This means that while the individual child and her needs are not forgotten, the practitioner is also aware of the potential for friendships and care that is located in the peer group and tries to support that potential. Three sub-patterns of group interactions were identified. The first is group interaction with a practitioner on the sideline. These are situations where a practitioner supports play in a peer group without directly participating in the play.

In one observation, a child (two years old) says he wants to balance on some square, hard pillows. The practitioner helps him and four other children who come up to them (all two years old) to create a narrow road of pillows. Four children start balancing on the road. The practitioner supports some of the children's performance of the activity. She gives them advice regarding turntaking and where to begin the walk, and she gives the youngest child a supporting hand when it is his turn to walk on the pillows. The children look and smile towards each other and laugh together on several occasions when they get physically close to each other. They often seem to take inspiration from each other in performing the walk.

The interaction appears to be inclusive; anyone who takes the initiative to participate gains access. The children have great freedom to perform the balancing act in their own way. The support the practitioner offers helps the group members regulate their physical actions to each other; however, it also seems to lay a foundation for developing a lively and respectful interaction among the children. Primarily, the children's attention is directed towards each other and the joint activity. The communication in the peer group is more nonverbal than verbal, and it can be interpreted as a joyful togetherness. This playful interaction can provide opportunities to experience the value of community in the peer group and build social belongingness between all the participants.

A practitioner who is standing on the sideline in a play situation can also offer the children more concrete help in developing a feeling of community. This could be done by appealing to the children to take care of each other, to show each other friendliness through a hug or a little pat, or by commenting on the children's cooperation or joint caretaking. However, there is only one tiny example of this in the research material.

A second sub-pattern is named group interaction with a practitioner as a play leader. In short, this refers to situations where the practitioner is assuming the role of leader during play. The practitioner's attention is primarily directed towards the interaction between the children. For example, she can try to initiate play between children who usually do not play together or lead play in a group with several children. For the youngest children, it may be a challenge to coordinate play on their own, in groups with more than two children. Commonly, practitioners take a leading role in the organization of play and give the children some support to establish and maintain a communicative interaction during the play period. In these situations, the adult is not alone in the centre of the lines of communication; the communication between the children is also central. Often, the children's communication is mostly nonverbal. A group interaction with a practitioner as a play leader may give the 
children opportunities to experience the value of the children's community and develop a sense of belonging to the peer group. However, the form and quality of the leadership will be crucial for the communication of values.

A third sub-pattern is named group interactions with a practitioner as a playmate. There are (quite a few) play situations in the research material where the practitioner takes the role of a playmate.

Two girls, both two years old, are playing sheep. They approach a practitioner, who is sitting by a table. The girls pretend to cautiously "eat" the practitioners' torso. The practitioner responds to this with a playful, scared voice: "Ohhh, someone is eating me." The two girls laugh and run away from her. A boy of the same age joins the play. The three children move around the table and approach the practitioner again. The practitioner takes part in the play and pretends she is very afraid of the animals. The interplay develops, and one of the girls asks the practitioner to catch them. The practitioner asks: "Do I have to catch the animals and put them in prison?" The children confirm eagerly. The practitioner starts to chase the children around in the department. She catches them and puts them in a "prison" under the table. Soon after, the children escape. The interplay develops with a lot of humor, playfulness, smiles, and laughter.

This situation is interpreted as a playful interaction involving both the practitioner and the three children. The actors relate to each other and adjust to the others' verbal or nonverbal initiatives. The children's verbal utterances are primarily directed towards the practitioner, but the nonverbal communication in the peer group is rich. The children follow each others' movements and seem to use each other as models, and one of the girls describes the peer group with the use of the plural pronoun us: "You have to catch us!" The practitioner complies and addresses the children, saying: "Do I have to catch the animals and put them..." In this way, she supports the children as a group and directs their attention not only towards herself, but also towards their peers. The communication in the peer group shows signs of shared joy and cooperation. The playful interaction provides opportunities to experience the value of community and joint activity in the peer group and build social belonging between the children.

It is the children who initiate common play with the practitioner. She is attentive towards the children and responds to their initiatives. On several occasions, she distributes power to the children (Malone and Hartung 2010). She allows the children to lead the play, supports their proposals, and exhibits a slightly subdued playfulness, where she expresses fear and insecurity facing the scary and dangerous animals. The practitioner is attentive towards the children's verbal and nonverbal inputs and relates to them both as individual subjects and as valuable members of a peer group. She recognizes their expressions by supporting their playful attitudes. The interaction seems to support a sense of belonging and community in the peer group.

\section{Summary}

The aim of the study was to investigate the interaction between children and practitioners in relation to democratic practices in preschool. Two categories of 
interaction patterns between children and practitioners in play situations have been identified: dyadic interactions and group interactions. In a dyadic interaction, the main lines of communication are between a practitioner and each child, while in a group interaction the lines are between a practitioner and the children as important members of a peer group. Different types of interactions provide the children with diverse opportunities to experience a sense of belonging and the value of community. In a dyadic interaction, the practitioner interacts with the children mainly as individuals. These interactions can provide opportunities for the children to develop a sense of belonging and experience the value of community with the practitioner. However, dyadic interactions provide limited opportunities to develop a feeling of shared involvement in the peer group and to experience the value of community among peers. There is a risk that children will experience other children more as competitors for practitioners' attention than as real playmates. In group interactions, the practitioner relates to the children both as individuals and as valuable members of a peer group. The practitioner can give the children concrete or more indirect support in building relationships among themselves. Group interactions provide more opportunities than dyadic interactions to develop a sense of belonging and community in the peer group.

The data present considerable variation in regard to how much attention and support the practitioners give to the youngest children's communities in play. If the dominant interaction pattern between practitioners and children is dyadic, it seems to convey an individualistic accentuation towards the children. According to Emilson and Johansson (2016), an individual-orientated approach to democracy is the most common in preschool. One way of describing this is that children's opportunities to experience participation, responsibility, and contribution to a larger collective, including both other children and the practitioner, with an emphasis on mutual relations, are not fully understood or utilized. Biesta (2011) maintains that children need a community within which to express their individuality based on pluralism and the recognition that there are different ways of expressing oneself. A stronger emphasis on the children's relationships can support connectedness and develop a sense of community in the peer group, providing the children with experiences of democratic values among peers.

Children assimilate democratic values from birth. The attitudes of practitioners influence children's understanding and respect for these values. Upholding democratic values in preschool practices requires practitioners to be aware of how values are communicated in daily interactions with the youngest children. The challenge raised by this study is to be cognizant of how interaction patterns in play situations may affect the youngest children's opportunities to experience the value of community and develop a sense of belonging with other children in the group.

This study makes a contribution by providing empirical data, regarding how democratic values are expressed in the interaction between practitioners and the youngest children in preschool. Dyadic interactions and group interactions provide the children with diverse opportunities to experience a sense of belonging and the value of community. While dyadic interactions mainly provide opportunities to develop a sense of belonging, and to experience the value of community with a practitioner, group interactions also provide opportunities to develop a sense of 
belonging and community within the peer group. Accordingly, group interactions compared to dyadic interactions can safeguard children's chances to experience democratic practices in a more comprehensive manner.

Acknowledgments I want to thank NordForsk for funding the project Values Education in Nordic preschools: Basis of education for tomorrow, Project No. 53381. I also want to thank my Nordic research colleagues for their constructive comments.

Open Access This article is distributed under the terms of the Creative Commons Attribution 4.0 International License (http://creativecommons.org/licenses/by/4.0/), which permits unrestricted use, distribution, and reproduction in any medium, provided you give appropriate credit to the original author(s) and the source, provide a link to the Creative Commons license, and indicate if changes were made.

\section{References}

Bae, B. (2009a). Rom for medvirkning? Samspillet mellom førskolelærer og barn [Space for participation? Interplay between preschool teacher and children]. Barn, 27(1), 9-28.

Bae, B. (2009b). Barns rett til medvirkning - fallgruver og muligheter [Children's right to participatePitfalls and opportunities]. Forste steg, 1, 12-16.

Biesta, G. (2011). Learning democracy in school and society: Education, lifelong learning, and the politics of citizenship. Rotterdam: Sense Publisher.

Cockburn, T. (2010). Children and deliberative democracy in England. In B. Percy-Smith \& N. Thomas (Eds.), A handbook of children and young people's participation: Perspectives from theory and practice (pp. 306-3018). London: Routledge.

Creswell, J. W. (2007). Qualitative inquiry \& research design: Choosing among five approaches. Thousand Oaks, CA: Sage.

Dewey, J. (1988/1939). Creative democracy: The task before us. In A. Boydstone (Ed.), John Dewey. The later works, 1925-1953. Volume 14: 1939-1941 (pp. 224-230). Carbondale IL: Southern Illinois University Press.

Dewey, J. (2008/1916). Democracy and education: An introduction to the philosophy of education. Champaign: Book Jungle.

Einarsdttir, J., Puroila, A.-M., Johansson, E., Broström, S., \& Emilson, A. (2015). Democracy, caring and competence: Values perspectives in ECEC curricula in the Nordic countries. International Journal of Early Years Education, 23(1), 97-114.

Emilson, A., \& Johansson, E. (2009). The desirable toddler in preschool: Values communicated in teacher and child interactions. In D. Berthelsen, J. Brownlee, \& E. Johansson (Eds.), Participatory learning in the early years: Research and pedagogy (pp. 61-78). London: Routledge.

Emilson, A., \& Johansson, E. (2016). Values in Nordic early childhood education - democracy and the child's perspective. In M. Fleer \& B. van Oers (Eds.), International handbook on early childhood education and development. Dordrecht: Springer.

Erickson, F. (2006). Definition and analysis of data from videotape: Some research procedures and their rationales. In J. L. Green, G. Camilli, \& P. B. Elmore (Eds.), Handbook of complementary methods in education research (pp. 177-189). Mahwah, NJ: Lawrence Erlbaum Associates.

Habermas, J. (1996). Kommunikativt handlande: Texter om språk, rationalitet och samhälle [Communicative action. Text about language, rationality and society]. Göteborg: Daidalos.

Hammersley, M., \& Atkinson, P. (1996). Ethnology principles in practice. London: Routledge.

Johansson, E., Fugelsnes, K., Mørkeseth, E. I., Röthle, M., Tofteland, B., \& Zachrisen, B. (2015). Verdipedagogikk $i$ barnehagen [Value education in kindergarten]. Oslo: Universitetsforlaget.

Malone, K., \& Hartung, C. (2010). Challenges of participatory practice with children. In B. Percy-Smith \& N. Thomas (Eds.), A handbook of children and young people's participation: Perspectives from theory and practice (pp. 24-39). London: Routledge.

Maslow, A. (1981). Abraham Maslow. Oslo: Dreyers Forlag.

Osler, A., \& Starkey, H. (2005). Changing citizenship. Berkshire, GBR: McGraw-Hill Education. 
Palludan, C. (2005). Børnehaven gфr en forskel [The kindergarten makes a difference]. København: Danmarks Pædagogiske Universitets Forlag.

Quennerstedt, A. (2011). The construction of children's rights in education: A research synthesis. International Journal of Children's Rights, 19, 661-678.

Tholin, K. R., \& Jansen, T. T. (2011). Demokratiske samtaler i barnehagen? [Democratic conversations in kindergarten]. Nordic Early Childhood Education Research, 4(2), 103-114.

Thomas, N., \& Percy-Smith, B. (2010). Introduction. In B. Percy-Smith \& N. Thomas (Eds.), A handbook of children and young people's participation: Perspectives from theory and practice (pp. 1-9). London: Routledge.

Walsh, D. J., Bakir, N., Lee, T. B., Chung, Y.-H., Chung, K., et al. (2007). Using digital video in fieldbased research with children: A primer. In J. A. Hatch (Ed.), Early childhood qualitative research (pp. 43-63). London: Routledge.

Walton, G. H., Cohen, G. L., Cwir, D., \& Spencer, S. J. (2012). Mere belonging: The power of social connections. Journal of Personal and Social Psychology, 102(3), 513-532. 